\title{
Alkaloids, Diarylheptanoid and Naphthalene Carboxylic Acid Ester from Rhoiptelea chiliantha
}

\author{
Zhi-Hong Jiang, Takashi Tanaka, Chizuko InUtsuka, and Isao Kouno* \\ School of Pharmaceutical Sciences, Nagasaki University, 1-14 Bunkyo-machi, Nagasaki 852-8521, Japan. \\ Received January 15, 2001; accepted March 6, 2001
}

Two pyrrolidine alkaloids $(1,2)$ were isolated from the fruits of Rhoiptelea chiliantha DIEL et HAND.-MAzz. (Rhoipteleaceae). A diphenyl ether-type diarylheptanoid (3), and a naphthalene carboxylic acid methyl ester (4) which is biogenetically-related to juglone were isolated from the branches of the same plant. Their chemical structures were elucidated on the basis of spectroscopic analysis and chemical evidence.

Key words Rhoiptelea chiliantha; Rhoipteleaceae; pyrrolidine alkaloid; diarylheptanoid; chemotaxonomy

In a series of papers on our chemical and chemotaxonomical studies of Rhoiptelea chiliantha Diel et HAND.-MAzZ., the only species of the family Rhoipteleaceae, we have reported the structural elucidation of triterpenes, ${ }^{1)}$ triterpene esters ${ }^{2}$ from the barks, diarylheptanoids, ${ }^{3)}$ ellagitannins, ${ }^{4)}$ euphanetype triterpene bisdesmosides and tridesmosides, ${ }^{5)}$ and dammmarane-type triterpene glycosides ${ }^{6}$ from the fruits and leaves. In a continuation of this investigation, we chemically studied the branches whose constituents have not yet been examined, and also further separated the composition of the fruits. Herein, we describe the structural elucidation of two pyrrolidine alkaloids (1 and 2) from the fruits, a diphenyl ether-type diarylheptanoid (3) and a naphthalene carboxylic acid methyl ester (4) which is biogenetically-related to juglone from the branches.

\section{Results and Discussion}

The $\mathrm{MeOH}$ extracts of the air-dried fruits and branches of Rhoiptelea chiliantha were separately partitioned between $\mathrm{H}_{2} \mathrm{O}$ and $\mathrm{Et}_{2} \mathrm{O}$, the remaining $\mathrm{H}_{2} \mathrm{O}$ layers were further extracted with EtOAc. The $\mathrm{H}_{2} \mathrm{O}$ layer of the fruits was subjected to column chromatography over MCI-gel CHP 20P, Bondapak ODS and silica gel to afford compounds $\mathbf{1}$ and $\mathbf{2}$. The $\mathrm{Et}_{2} \mathrm{O}$ layer of the branch was chromatographed over silica gel and MCI-gel CHP 20P to yield compound 3. The $\mathrm{H}_{2} \mathrm{O}$ layer of the branches was chromatographed over Sephadex LH-20 and silica gel to afford compound 4.

Compound 1 was isolated from the fruits as colorless needles, mp $178-180^{\circ} \mathrm{C}$. It showed a pink spot on TLC when sprayed with ninhydrin reagent followed by heating, indicating the existence of nitrogen atom in its molecule. The molecular formula of 1 was established to be $\mathrm{C}_{13} \mathrm{H}_{17} \mathrm{NO}_{3}$ on the basis of the molecular ion peak at $m / z: 235$ in EI-MS and the result of elemental analysis, suggesting that $\mathbf{1}$ is an alkaloid. Its ${ }^{1} \mathrm{H}-\mathrm{NMR}$ spectrum displayed the signals due to a 1,2,3trisubstituted benzene ring $\left[\delta_{\mathrm{H}} 7.50(1 \mathrm{H}, \mathrm{dd}, J=2,8 \mathrm{~Hz})\right.$, $7.36(1 \mathrm{H}, \mathrm{dd}, J=8,9 \mathrm{~Hz}), 7.11(1 \mathrm{H}, \mathrm{dd}, J=2,9 \mathrm{~Hz})]$, an $N$ methyl $\left[\delta_{\mathrm{H}} 2.62(3 \mathrm{H}, \mathrm{s})\right]$ and a methoxyl group $\left[\delta_{\mathrm{H}} 3.87(3 \mathrm{H}\right.$, $\mathrm{s})$ ]. Besides these, the signals arising from a carboxylic carbon, a methine $\left[\delta_{\mathrm{C}} 62.4(\mathrm{~d}, \mathrm{C}-2)\right]$, and three methylenes $\left[\delta_{\mathrm{C}}\right.$ $54.8(\mathrm{t}, \mathrm{C}-5), 31.0(\mathrm{t}, \mathrm{C}-3), 22.6(\mathrm{t}, \mathrm{C}-4)]$ were confirmed by the ${ }^{13} \mathrm{C}$-NMR and DEPT spectra. The correlations (Fig. 1) of the methylenes and methine in the ${ }^{1} \mathrm{H}-{ }^{1} \mathrm{H}$ COSY spectrum and their chemical shifts suggested the presence of a 2-substituted pyrrolidine ring in compound 1. ${ }^{7)}$ The HMBC corre- lations shown in Fig. 1 determined the positions of the carboxylic acid group and methoxyl group in C-2' and C- $6^{\prime}$, respectively, in the benzene ring. Furthermore, the HMBC correlations from $\mathrm{H}-2$ signal to $\mathrm{C}-1^{\prime}, \mathrm{C}-2^{\prime}$ and $\mathrm{C}-6^{\prime}$ signals confirmed the linkage of 2-substituted pyrrolidine ring to the benzene ring at $\mathrm{C}-1^{\prime}$ position. Thus, the plain structure of $\mathbf{1}$ was concluded to be as shown in Fig. 1. The absolute configuration of C-2 of 1 was determined to be $R$ on the basis of observation of a negative Cotton effect at $246 \mathrm{~nm}$ in the CD spectrum. ${ }^{7)}$

Compound 2 was also isolated from the fruits as colorless crystals, mp $221-223^{\circ} \mathrm{C}$ and showed a positive reaction to ninhydrin reagent on TLC by heating. Its molecular formula of $\mathrm{C}_{12} \mathrm{H}_{15} \mathrm{NO}_{2}$ was deduced from the data of EI-MS spectrum (molecular ion peak at $\mathrm{m} / z 205[\mathrm{M}]^{+}$) and elemental analysis. The ${ }^{1} \mathrm{H}$ - and ${ }^{13} \mathrm{C}-\mathrm{NMR}$ data of 2 were very similar to those of 1, exhibiting a 2-substituted pyrrolidine ring, a carboxylic acid group, an $N$-methyl group and a benzene ring. However, the presence of a 1,2-disubstituted benzene ring in $\mathbf{2}$ instead of a trisubstituted one in $\mathbf{1}$, and the absence of methoxyl group in $\mathbf{2}$ indicated that there is no methoxyl group in C-6 of the benzene ring. By comparing the NMR data of 2 with those of dihydroshihunine isolated from Banisteriopsis cappi (Malpighiaceae), ${ }^{7)} \mathbf{2}$ was determined to possess a plain structure the same as dihydroshihunine. But the sign of the optical rotation of $2\left(-257.4^{\circ}\right)$ is opposite to that $\left(+234.7^{\circ}\right)$ of $2 S$ dihydroshihunine, suggesting $\mathbf{2}$ has a $2 R$ configuration. Additionally, the appearance of a negative Cotton effect at $244 \mathrm{~nm}$ in the CD spectrum of $\mathbf{2}$ also confirmed this conclusion. From the above evidence, compound $\mathbf{2}$ was assigned to $2 R$ dihydroshihunine.

Compound 3 was isolated from the branches as a white amorphous powder which showed an $[\mathrm{M}]^{+}$ion peak at $\mathrm{m} / \mathrm{z}$

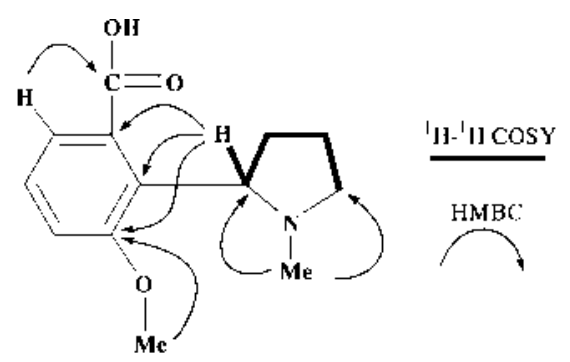

Fig. 1. Selected ${ }^{1} \mathrm{H}-{ }^{1} \mathrm{H}$ COSY and HMBC Correlations of Compound $\mathbf{1}$ 


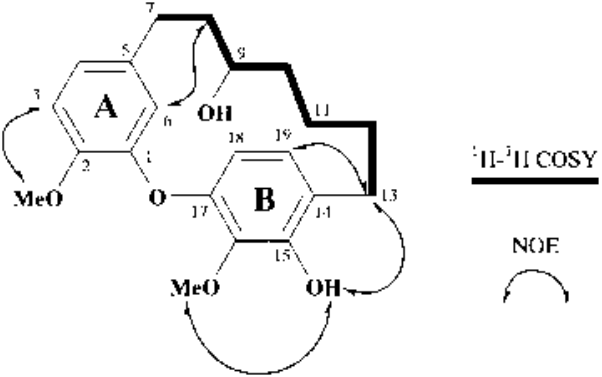

Fig. 2. ${ }^{1} \mathrm{H}-{ }^{1} \mathrm{H}$ COSY and NOE Correlations of Compound 3

358 in the EI-MS spectrum. Taking the ${ }^{13} \mathrm{C}$-NMR data and the result of elemental analysis into account, the molecular formula of 3 was established to be $\mathrm{C}_{21} \mathrm{H}_{26} \mathrm{O}_{5}$. In the ${ }^{13} \mathrm{C}$ NMR spectrum, the signals due to two aromatic nuclei and seven aliphatic carbons along with two methoxyl groups were observed, indicating that $\mathbf{3}$ is a diarylheptanoid. Analysis of the aromatic signals in the ${ }^{1} \mathrm{H}-\mathrm{NMR}$ spectra suggested the presence of a 1,2,3,4-tetrasubstituted $\left[\delta_{\mathrm{H}} 6.89(1 \mathrm{H}, \mathrm{d}\right.$, $J=8 \mathrm{~Hz}, \mathrm{H}-19), 6.69(1 \mathrm{H}, \mathrm{d}, J=8 \mathrm{~Hz}, \mathrm{H}-18)]$ and a $1,3,4-$ trisubstituted benzene ring $\left[\delta_{\mathrm{H}} 6.84(1 \mathrm{H}, \mathrm{d}, J=8 \mathrm{~Hz}, \mathrm{H}-3)\right.$, $6.70(1 \mathrm{H}, \mathrm{dd}, J=2,8 \mathrm{~Hz}, \mathrm{H}-4), 5.72(1 \mathrm{H}, \mathrm{d}, J=2 \mathrm{~Hz}, \mathrm{H}-6)]$. In addition, a phenolic hydroxyl $\left[\delta_{\mathrm{H}} 5.93(1 \mathrm{H}, \mathrm{s}, 15-\mathrm{OH})\right]$ and an alcoholic hydroxyl $\left[\delta_{\mathrm{H}} 1.25(1 \mathrm{H}, \mathrm{s}, 9-\mathrm{OH})\right]$ which were exchangeable with $\mathrm{D}_{2} \mathrm{O}$, and two methoxyl groups $\left[\delta_{\mathrm{H}}\right.$ 4.00, 3.98 (each $3 \mathrm{H}, \mathrm{s}$ )] were also confirmed in the ${ }^{1} \mathrm{H}-\mathrm{NMR}$ spectrum. The ${ }^{1} \mathrm{H}$ - and ${ }^{13} \mathrm{C}-\mathrm{NMR}$ spectral data mentioned above are very similar to those of platycarynol ${ }^{8)}(\mathbf{5})$ isolated from Platycarya strobilacea (Juglandaceae), suggesting that 3 is a diphenyl ether-type diarylheptanoid. The correlations of the aliphatic protons in the ${ }^{1} \mathrm{H}-{ }^{1} \mathrm{H}$ COSY spectrum displayed the connectivities from C-7 to C-13 (Fig. 2), revealing the location of a hydroxyl group at C-9 position. The NOE correlations between $\mathrm{H}-13$ and $\mathrm{H}-19$, between $\mathrm{H}-13$ and phenolic hydroxyl, and between H-6 and H-8 which were observed in the NOE spectrum of 3 revealed the linkage of C-7 to $\mathrm{C}-5$ of benzene ring $\mathrm{A}$ and $\mathrm{C}-13$ to $\mathrm{C}-14$ of benzene ring $\mathrm{B}$ (Fig. 2). Furthermore, the NOE correlations between $\mathrm{H}-3$ and methoxyl $\left(\delta_{\mathrm{H}}\right.$ 3.98), between phenolic hydroxyl and methoxyl $\left(\delta_{\mathrm{H}} 4.00\right)$ indicated the positions of methoxyls and hydroxyl in benzene rings. Hence, the linkage diphenyl ether is determined to be between $\mathrm{C}-1$ and $\mathrm{C}-17$. From the above evidence, the plain structure of $\mathbf{3}$ was determined to be as shown in Fig. 2.

To determine the absolute configuration of the secondary hydroxyl group at $\mathrm{C}-9,3$ was methylated with $\mathrm{CH}_{2} \mathrm{~N}_{2}$ to give 3a which was further esterified by $(R)$ - $\alpha$-methoxy- $\alpha$-(trifluoromethyl)-phenylacetic acid (MTPA) and ( $S$ )-MTPA, respectively. By applying the modification of Mosher's method ${ }^{9)}$ to the MTPA esters $(\mathbf{3 b}, \mathbf{c})$ of $\mathbf{3 a}$, the positive and negative $\Delta \delta$ $\left(\delta_{S}-\delta_{R}\right)$ values shown in Fig. 3 unequivocally indicated a $9 R$ configuration in compound $\mathbf{3}$.

The negative Cotton effect at $241 \mathrm{~nm}$ and the positive one at $218 \mathrm{~nm}$ in the CD spectrum suggested the chiral plane of $\mathbf{3}$ is expressed as $S$ configuration which is the same as that of (-)-galeon, a diarylheptanoid isolated from the Myrica plant. $^{10)}$

Compound $\mathbf{4}$ was isolated as a light yellow powder from the branches. Its molecular formula was determined to be

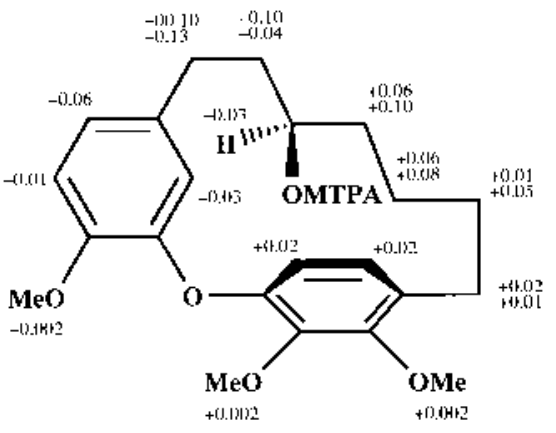

Fig. 3. $\Delta \delta\left(\delta_{S}-\delta_{R}\right)$ Values Obtained from MTPA Esters of Compound 3a

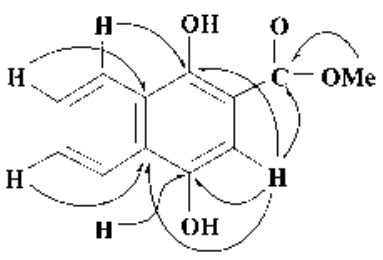

Fig. 4. HMBC Correlations of Compound 4<smiles>[2H]c1cccc([2H])c1C1(C=C)CCCN1C</smiles>

$1 \mathrm{~K}=\mathrm{OM} \mathrm{M}$

$2 \mathrm{R}=\mathrm{H}$

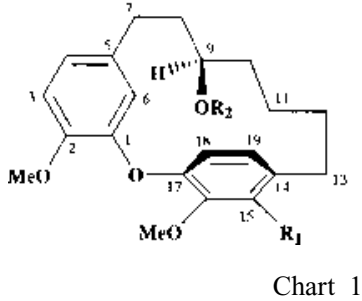

$\mathrm{C}_{12} \mathrm{H}_{10} \mathrm{O}_{4}$ by high resolution EI-MS. The ${ }^{1} \mathrm{H}-\mathrm{NMR}$ spectrum displayed the signals derived from a 1,2-disubstituted benzene ring $\left[\delta_{\mathrm{H}} 8.32(1 \mathrm{H}, \mathrm{dd}, J=1,8 \mathrm{~Hz}), 8.16(1 \mathrm{H}, \mathrm{dd}, J=1\right.$, $8 \mathrm{~Hz}), 7.61(1 \mathrm{H}, \mathrm{dt}, J=1,8 \mathrm{~Hz}), 7.53(1 \mathrm{H}, \mathrm{dt}, J=1,8 \mathrm{~Hz})]$, a singlet aromatic signal $\left(\delta_{\mathrm{H}} 7.11\right)$ and a methoxyl group $\left(\delta_{\mathrm{H}}\right.$ 3.98). The ${ }^{13} \mathrm{C}$-NMR spectral data indicated the presence of an ester carbonyl $\left(\delta_{\mathrm{C}} 172.2\right)$, a methoxyl group $\left(\delta_{\mathrm{C}} 52.6\right)$ and 10 aromatic signals, suggesting 4 is a naphthalene carboxylic acid methyl ester. Therefore, the remaining residues of 4 are deduced to be two hydroxyl groups. The carbonyl and these two hydroxyl groups were determined to be located in C-2, $\mathrm{C}-1$ and $\mathrm{C}-4$, respectively, of the naphthalene ring by the HMBC correlations shown in Fig. 4. A glucoside of hydroxynaphthalene carboxylic acid methyl ester related to 4 was reported to be present in Juglans mandshurica (Juglandaceae). ${ }^{11)}$

Compound 4, a methyl ester of compound 6, may be an artifact produced in the course of plant extraction or isolation. Compound $\mathbf{6}$ is a biogenetically important intermediate in the biosynthesis of juglone from $O$-succinoylbenzoic acid ${ }^{12}$ ) (Chart 1). 
In conclusion, we have isolated four new compounds (14) from the fruits and branches of Rhoiptelea chiliantha (Rhoipteleaceae). Compounds $\mathbf{1}$ and $\mathbf{2}$ belong to pyrrolidinetype alkaloids. Interestingly, compound 2 possesses an antipodal structure of $2 S$-dihydroshihunine which was isolated from Banisteriopsis cappi (Malpighiaceae). ${ }^{7)}$ Compound 3 has the same skeleton as $\mathbf{5}$ which was isolated from Platycarya strobilacea (Juglandaceae) in our previous paper. ${ }^{8)}$ Compound $\mathbf{4}$ is considered to be biogenetically-related to juglone which is widely distributed in Juglandaceous plants.

Chemotaxonomic studies on the Rhoipteleaceae based on our extensive and detailed investigations on the chemical constituents of Rhoiptelea chiliantha Diel et HAND.-MAzz. ${ }^{1-6)}$ have suggested the relationships of the order Rhoipteleales (comprising Rhoipteleaceae) to the Juglandales (comprising Juglandaceae), Fagales (comprising Betulaceae and Fagaceae) and Myricales (comprising Myriaceae). ${ }^{3)}$ The existence of $\mathbf{3}$ and $\mathbf{4}$ reported in the present paper further supported the affinity of a systematic position between the Rhoipteleales and Juglandales, and suggested the Juglandales is probably the most closely related order to the Rhoipteleales.

\section{Experimental}

General Melting points were determined on a micromelting point hot stage apparatus (Yanagimoto) and are uncorrected. Optical rotations were measured with a JASCO DIP-370 digital polarimeter. The CD spectra were measured with a JASCO J-725 apparatus. ${ }^{1} \mathrm{H}$ - and ${ }^{13} \mathrm{C}-\mathrm{NMR}$ spectra were recorded on Varian Unity plus 500, Varian Gemini 300 and Varian Gemini 200 spectrometers. Coupling constants $(J)$ are expressed in $\mathrm{Hz}$, and chemical shifts are given on a $\delta(\mathrm{ppm})$ scale with tetramethylsilane as an internal standard. FAB-MS were recorded on a JEOL JMS DX-303 spectrometer with glycerol as a matrix. Column chromatographies were performed with Kieselgel 60 (70-230 mesh, Merck), Sephadex LH-20 (25-100 $\mu \mathrm{m}$, Pharmacia Fine Chemical Co., Ltd.) and MCI-gel CHP 20P $(75-150 \mu \mathrm{m}$, Mitsubishi Chemical Co., Ltd.). Thin layer chromatography (TLC) was performed on precoated Kieselgel $60 \mathrm{~F}_{254}$ plates $(0.2 \mathrm{~mm}$ thick, Merck), and spots were detected by ultraviolet (UV) illumination and by spraying $10 \%$ sulfuric acid reagent or 2\% ninhydrin in EtOH.

Plant Material The fruits and branches of Rhoiptelea chiliantha were collected in Guangxi, China in Oct., 1988. A voucher specimen has been deposited in the Laboratory of Plant Chemotaxonomy, China Pharmaceutical University, Nanjing, China.

Extraction and Isolation The $\mathrm{MeOH}$ extracts of the air-dried fruits $(495 \mathrm{~g})$ and branches $(820 \mathrm{~g})$ of Rhoiptelea chiliantha were separately suspended in $\mathrm{H}_{2} \mathrm{O}$, then successively extracted with $\mathrm{Et}_{2} \mathrm{O}$ and EtOAc. The water layer of the fruits was chromatographed over MCI-gel CHP 20P $(0-$ $100 \% \mathrm{MeOH})$ to give fr.-1 (1.6 g), fr.-2 $(0.9 \mathrm{~g})$ and fr.-3 (13.7 g). Fraction-2 was subjected to Bondapak ODS $(0-40 \% \mathrm{MeOH})$ and silica gel $\left(\mathrm{CHCl}_{3}: \mathrm{MeOH}: \mathrm{H}_{2} \mathrm{O}, 9: 1: 0.1-8: 2: 0.2\right)$ column chromatographies to afford $1(274 \mathrm{mg})$ and $2(130 \mathrm{mg})$. The $\mathrm{Et}_{2} \mathrm{O}$ layer $(15.2 \mathrm{~g})$ of branches was separated into fr.-1 $(0.9 \mathrm{~g})$, fr.-2 $(4.7 \mathrm{~g})$ and fr.-3 $(5.8 \mathrm{~g})$ by column chromatography on silica gel $\left(\mathrm{CHCl}_{3}: \mathrm{MeOH}: \mathrm{H}_{2} \mathrm{O}, 10: 0: 0-7: 3: 0.5\right)$. Fraction-2 was chromatographed over MCI-gel CHP 20P $(80-100 \% \mathrm{MeOH})$ and silica gel (hexane: EtOAc, $2: 1-1: 1)$ to afford $3(276 \mathrm{mg})$. The $\mathrm{H}_{2} \mathrm{O}$ layer of the branches was subjected to Sephadex LH-20 column chromatography to afford fr.-1 (17.3 g), fr.-2 (2.9 g) and fr.-3 (4.0 g). Fraction-2 was separated by silica gel chromatography $\left(\mathrm{CHCl}_{3}: \mathrm{MeOH}: \mathrm{H}_{2} \mathrm{O}, 9: 1: 0.0\right.$ $8: 2: 0.2)$ to yield $4(162 \mathrm{mg})$.

Compound 1: Colorless needles, mp $178-180^{\circ} \mathrm{C},[\alpha]_{\mathrm{D}}^{15}-189.4^{\circ}(c=0.5$, $\mathrm{CHCl}_{3}$ ). Anal. Calcd for $\mathrm{C}_{13} \mathrm{H}_{17} \mathrm{NO}_{3} \cdot 3 / 4 \mathrm{H}_{2} \mathrm{O}: \mathrm{C}, 62.76 ; \mathrm{H}, 7.49 ; \mathrm{N}, 5.63$. Found: C, 62.80; H, 7.15; N, 5.54. EI-MS $m / z$ : $235\left(\mathrm{M}^{+}\right), 220\left(\mathrm{M}^{+}-\mathrm{CH}_{3}\right)$. ${ }^{1} \mathrm{H}-\mathrm{NMR}\left(500 \mathrm{MHz}\right.$, acetone- $\left.d_{6}\right): \delta_{\mathrm{H}} 7.50\left(1 \mathrm{H}, \mathrm{dd}, J=2,8 \mathrm{~Hz}, \mathrm{H}-3^{\prime}\right), 7.36$ $\left(1 \mathrm{H}, \mathrm{dd}, J=8,9 \mathrm{~Hz}, \mathrm{H}-4^{\prime}\right), 7.11\left(1 \mathrm{H}, \mathrm{dd}, J=2,9 \mathrm{~Hz}, \mathrm{H}-5^{\prime}\right), 4.96(1 \mathrm{H}, \mathrm{dd}$, $J=10,11 \mathrm{~Hz}, \mathrm{H}-2), 3.87$ ( $3 \mathrm{H}, \mathrm{s}, \mathrm{OMe}), 3.83(1 \mathrm{H}, \mathrm{ddd}, J=4,8,11 \mathrm{~Hz}, \mathrm{H}-5 \mathrm{a}$ ), $3.16(1 \mathrm{H}, \mathrm{dt}, J=11,10 \mathrm{~Hz}, \mathrm{H}-5 \mathrm{~b}), 2.62(3 \mathrm{H}, \mathrm{s}, \mathrm{NMe}), 2.33(1 \mathrm{H}, \mathrm{m}, \mathrm{H}-3 \mathrm{a})$, $2.19\left(2 \mathrm{H}, \mathrm{m}, \mathrm{H}_{2}-4\right), 2.11(1 \mathrm{H}, \mathrm{m}, \mathrm{H}-3 \mathrm{~b}) .{ }^{13} \mathrm{C}-\mathrm{NMR}\left(125 \mathrm{MHz}\right.$, acetone- $\left.d_{6}\right)$ : $\delta_{\mathrm{C}} 172.8\left(\mathrm{~s}, \mathrm{C}-7^{\prime}\right), 158.7\left(\mathrm{~s}, \mathrm{C}-6^{\prime}\right), 142.0\left(\mathrm{~s}, \mathrm{C}-2^{\prime}\right), 130.3\left(\mathrm{~d}, \mathrm{C}-4^{\prime}\right), 125.1(\mathrm{~d}$, C-3'), $120.8\left(\mathrm{~s}, \mathrm{C}-1^{\prime}\right), 112.9\left(\mathrm{~d}, \mathrm{C}-5^{\prime}\right), 62.4(\mathrm{~d}, \mathrm{C}-2), 56.7$ (q, OMe), $54.8(\mathrm{t}$,
C-5), 37.4 (q, NMe), 31.0 (t, C-3), 22.6 (t, C-4). CD ( $c=0.011, \mathrm{MeOH})[\theta]^{25}$ $(\mathrm{nm}):-1.9 \times 10^{4}(246)$.

Compound 2 ( $R$-dihydroshihunine): Colorless needles, mp $221-223{ }^{\circ} \mathrm{C}$, $[\alpha]_{\mathrm{D}}^{25}-257.4^{\circ}\left(c=0.2, \mathrm{CHCl}_{3}\right)$. Anal. Calcd for $\mathrm{C}_{12} \mathrm{H}_{15} \mathrm{NO}_{2} \cdot 1 / 4 \mathrm{H}_{2} \mathrm{O}: \mathrm{C}$, 68.71; H, 7.45; N, 6.68. Found: C, 69.18; H, 7.31; N, 6.71. EI-MS m/z: 205 $\left(\mathrm{M}^{+}\right), 195\left(\mathrm{M}^{+}-\mathrm{CH}_{3}\right) .{ }^{1} \mathrm{H}-\mathrm{NMR}\left(300 \mathrm{MHz}, \mathrm{CDCl}_{3}\right): \delta_{\mathrm{H}} 8.19(1 \mathrm{H}, \mathrm{dd}, J=2$, $\left.7 \mathrm{~Hz}, \mathrm{H}-3^{\prime}\right), 7.44,7.39$ (each $\left.1 \mathrm{H}, \mathrm{dt}, J=2,7 \mathrm{~Hz}, \mathrm{H}-4^{\prime}, 5^{\prime}\right), 7.22(1 \mathrm{H}, \mathrm{dd}$, $\left.J=2,7 \mathrm{~Hz}, \mathrm{H}-6^{\prime}\right), 3.73(1 \mathrm{H}, \mathrm{t}, J=9 \mathrm{~Hz}, \mathrm{H}-2), 3.61(1 \mathrm{H}, \mathrm{m}, \mathrm{H}-5 \mathrm{a}), 2.83(1 \mathrm{H}$, dt, $J=9,10 \mathrm{~Hz}, \mathrm{H}-5 \mathrm{~b}), 2.49$ (3H, s, NMe), 2.08-2.44 (4H, m, $\left.\mathrm{H}_{2}-3, \mathrm{H}_{2}-4\right)$; ${ }^{1} \mathrm{H}-\mathrm{NMR}\left(300 \mathrm{MHz}\right.$, acetone- $\left.d_{6}\right): \delta_{\mathrm{H}} 7.99\left(1 \mathrm{H}, \mathrm{dd}, J=2,7 \mathrm{~Hz}, \mathrm{H}-3^{\prime}\right), 7.45$ $\left(3 \mathrm{H}, \mathrm{m}, \mathrm{H}-4^{\prime}, 5^{\prime}, 6^{\prime}\right), 4.33(1 \mathrm{H}, \mathrm{t}, J=9 \mathrm{~Hz}, \mathrm{H}-2), 3.91(1 \mathrm{H}, \mathrm{dt}, J=12,5 \mathrm{~Hz}$, $\mathrm{H}-5 \mathrm{a}), 3.24(1 \mathrm{H}, \mathrm{dt}, J=12,9 \mathrm{~Hz}, \mathrm{H}-5 \mathrm{~b}), 2.72(3 \mathrm{H}, \mathrm{s}, \mathrm{NMe}), 2.48(1 \mathrm{H}, \mathrm{m}, \mathrm{H}-$ 3a), $2.23\left(3 \mathrm{H}, \mathrm{m}, \mathrm{H}-3 \mathrm{~b}, \mathrm{H}_{2}-4\right) .{ }^{13} \mathrm{C}-\mathrm{NMR}\left(75 \mathrm{MHz}, \mathrm{CDCl}_{3}\right): \delta_{\mathrm{C}} 171.3$ (s, C$\left.7^{\prime}\right), 135.6\left(\mathrm{~s}, \mathrm{C}-1^{\prime}\right), 134.2\left(\mathrm{~s}, \mathrm{C}-2^{\prime}\right), 134.0\left(\mathrm{~d}, \mathrm{C}-5^{\prime}\right), 131.0\left(\mathrm{~d}, \mathrm{C}-3^{\prime}\right), 130.6$ (d, C-4'), 129.2 (d, C-6'), 73.1 (d, C-2), 54.6 (t, C-5), 37.8 (q, NMe), 32.4 (t, C-3), 22.0 (t, C-4); ${ }^{13} \mathrm{C}-\mathrm{NMR}\left(75 \mathrm{MHz}\right.$, acetone- $\left.d_{6}\right): \delta_{\mathrm{C}} 173.4$ (s, C-7'), $138.9\left(\mathrm{~s}, \mathrm{C}-1^{\prime}\right), 133.3\left(\mathrm{~d}, \mathrm{C}-5^{\prime}\right), 133.0\left(\mathrm{~s}, \mathrm{C}-2^{\prime}\right), 132.6\left(\mathrm{~d}, \mathrm{C}-3^{\prime}\right), 130.8$ (d, C$\left.4^{\prime}\right), 130.0\left(\mathrm{~d}, \mathrm{C}-6^{\prime}\right), 73.3(\mathrm{~d}, \mathrm{C}-2), 55.2(\mathrm{t}, \mathrm{C}-5), 37.4$ (q, NMe), $32.0(\mathrm{t}, \mathrm{C}-3)$, $22.4(\mathrm{t}, \mathrm{C}-4)$. CD $(c=0.0032, \mathrm{MeOH})[\theta]^{25}(\mathrm{~nm}):-2.4 \times 10^{4}(244)$.

Compound 3: A white amorphous powder, $[\alpha]_{\mathrm{D}}^{15}-58.5^{\circ}\left(c=0.3, \mathrm{CHCl}_{3}\right)$. Anal. Calcd for $\mathrm{C}_{21} \mathrm{H}_{26} \mathrm{O}_{5}: \mathrm{C}, 70.37 ; \mathrm{H}, 7.31$. Found: C, 69.95; H, 7.25. EIMS $m / z: 358\left(\mathrm{M}^{+}\right) .{ }^{1} \mathrm{H}-\mathrm{NMR}\left(500 \mathrm{MHz}, \mathrm{CDCl}_{3}\right): \delta_{\mathrm{H}} 6.89(1 \mathrm{H}, \mathrm{d}, J=8 \mathrm{~Hz}$, $\mathrm{H}-19), 6.84(1 \mathrm{H}, \mathrm{d}, J=8 \mathrm{~Hz}, \mathrm{H}-3), 6.70(1 \mathrm{H}, \mathrm{dd}, J=2,8 \mathrm{~Hz}, \mathrm{H}-4), 6.69(1 \mathrm{H}$, d, $J=8 \mathrm{~Hz}, \mathrm{H}-18), 5.93(1 \mathrm{H}, \mathrm{s}, 15-\mathrm{OH}), 5.72(1 \mathrm{H}, \mathrm{d}, J=2 \mathrm{~Hz}, \mathrm{H}-6), 4.00$ $(3 \mathrm{H}, \mathrm{s}, 16-\mathrm{OMe}), 3.98(3 \mathrm{H}, \mathrm{s}, 2-\mathrm{OMe}), 3.14(1 \mathrm{H}, \mathrm{m}, \mathrm{H}-9), 3.11(1 \mathrm{H}, \mathrm{m}, \mathrm{H}-$ 13a), $2.64(1 \mathrm{H}$, ddd, $J=4,10,17 \mathrm{~Hz}, \mathrm{H}-7 \mathrm{a}), 2.55(1 \mathrm{H}$, ddd, $J=4,6,17 \mathrm{~Hz}$, $\mathrm{H}-7 \mathrm{~b}), 2.38(1 \mathrm{H}$, ddd, $J=4,7,13 \mathrm{~Hz}, \mathrm{H}-13 \mathrm{~b}), 1.83(1 \mathrm{H}, \mathrm{m}, \mathrm{H}-12 \mathrm{a}), 1.50$ (3H, m, $\left.\mathrm{H}_{2}-8, \mathrm{H}-12 \mathrm{~b}\right), 1.25$ (3H, m, H-10a, 11a, 9-OH), $1.15(1 \mathrm{H}, \mathrm{m}, \mathrm{H}-$ 11b), $1.04(1 \mathrm{H}, \mathrm{m}, \mathrm{H}-10 \mathrm{~b}) .{ }^{13} \mathrm{C}-\mathrm{NMR}\left(75 \mathrm{MHz}, \mathrm{CDCl}_{3}\right): \delta_{\mathrm{C}} 149.3(\mathrm{~s}), 147.9$ (s), $146.29(\mathrm{~s}), 146.26(\mathrm{~s}), 140.1(\mathrm{~s}), 134.7(\mathrm{~s}), 126.1(\mathrm{~s}), 125.4(\mathrm{~d}), 122.2$ (d), 115.9 (d), 114.1 (d), 112.0 (d), 71.8 (d, C-9), 61.7, 56.2 (each q, 2, 16OMe), $38.4(t), 36.1(t), 28.9(t), 28.7(t), 28.3(t), 22.4(t) . C D(c=0.0016$, $\mathrm{MeOH})[\theta]^{25}(\mathrm{~nm}):+4.42 \times 10^{4}(218),-3.24 \times 10^{4}(241),-1.15 \times 10^{4}(283)$.

Methylation of 3 A solution of $3(142 \mathrm{mg})$ in $\mathrm{MeOH}$ was treated with $\mathrm{CH}_{2} \mathrm{~N}_{2}$ in $\mathrm{Et}_{2} \mathrm{O}$ at room temperature. The reaction mixture was evaporated in vacuo, and the residue was separated with silica gel (hexane: EtOAc, $4: 1-$ $1: 1)$ to give 3a $(28.2 \mathrm{mg})$ : a white amorphous powder, $[\alpha]_{\mathrm{D}}^{15}-4.5^{\circ}(c=0.9$, $\left.\mathrm{CHCl}_{3}\right)$. EI-MS $m / z: 372\left(\mathrm{M}^{+}\right) .{ }^{1} \mathrm{H}-\mathrm{NMR}\left(200 \mathrm{MHz}, \mathrm{CDCl}_{3}\right): \delta_{\mathrm{H}} 6.95,6.92$ (each $1 \mathrm{H}, \mathrm{d}, J=8 \mathrm{~Hz}, \mathrm{H}-18, \mathrm{H}-19), 6.69(1 \mathrm{H}, \mathrm{dd}, J=2,8 \mathrm{~Hz}, \mathrm{H}-4), 6.84(1 \mathrm{H}$, d, $J=8 \mathrm{~Hz}, \mathrm{H}-3$ ), 5.74 (1H, d, $J=2 \mathrm{~Hz}, \mathrm{H}-6), 3.96,3.83,3.79$ (each $3 \mathrm{H}, \mathrm{s}, 4$, 5, 19-OMe), 3.15 (1H, m, H-9), 3.10 (1H, m, H-13a), 2.51 (2H, m, H2-7), $2.40(1 \mathrm{H}, \mathrm{m}, \mathrm{H}-13 \mathrm{~b})$.

Preparation of MTPA Esters of 3a A solution of 3a $(5 \mathrm{mg})$, dicyclohexylcarbodiimide $(8 \mathrm{mg})$, 4-dimethylaminopyridine $(6 \mathrm{mg})$ and $(R)-(+)-\alpha$ methoxy- $\alpha$-(trifluoromethyl)-phenylacetic acid $(8 \mathrm{mg})$ in $\mathrm{CH}_{2} \mathrm{Cl}_{2}$ was allowed to stand at room temperature for $18 \mathrm{~h}$. The resulting mixture was purified over a micro-column $(0.7 \times 7 \mathrm{~cm})$ of silica gel (hexane: EtOAc, $8: 1-$ $6: 1)$ to afford (R)-MTPA ester $3 \mathbf{b}(3 \mathrm{mg})$. The use of $(S)-(-)$ - $\alpha$-methoxy- $\alpha$ (trifluoromethyl)-phenylacetic acid gave the $(S)$-MTPA ester $3 \mathbf{c}(3 \mathrm{mg})$.

Compound 4: A light yellow amorphous powder. HR-EI-MS $m / z$ : $218.0561\left(\mathrm{M}^{+}\right)$(Calcd for $\left.\mathrm{C}_{12} \mathrm{H}_{10} \mathrm{O}_{4}: 218.0579\right)$. ${ }^{1} \mathrm{H}-\mathrm{NMR}(500 \mathrm{MHz}$, $\left.\mathrm{CD}_{3} \mathrm{OD}\right): \delta_{\mathrm{H}} 8.32(1 \mathrm{H}, \mathrm{dd}, J=1,8 \mathrm{~Hz}, \mathrm{H}-8), 8.16(1 \mathrm{H}, \mathrm{dd}, J=1,8 \mathrm{~Hz}, \mathrm{H}-5)$, $7.61(1 \mathrm{H}, \mathrm{dt}, J=1,8 \mathrm{~Hz}, \mathrm{H}-6), 7.53(1 \mathrm{H}, \mathrm{dt}, J=1,8 \mathrm{~Hz}, \mathrm{H}-7), 7.11(1 \mathrm{H}, \mathrm{s}, \mathrm{H}-$ 3), $3.98(3 \mathrm{H}, \mathrm{s}, \mathrm{OMe}) .{ }^{13} \mathrm{C}-\mathrm{NMR}\left(125 \mathrm{MHz}, \mathrm{CD}_{3} \mathrm{OD}\right): \delta_{\mathrm{C}} 172.2(\mathrm{~s}, \mathrm{C}-11)$, 155.0 (s, C-1), 145.7 (s, C-4), 130.5 (s, C-10), 129.2 (d, C-6), 126.7 (d, C-7), 126.2 (s, C-9), 124.2 (d, C-8), 122.8 (d, C-5), 105.4 (s, C-2), 105.0 (d, C-3), $52.6(\mathrm{q}, \mathrm{OMe})$.

Acknowledgements This work was financially supported by a Grant-inAid for Scientific Research (No. 07672273) from the Ministry of Education, Science Sports and Culture, Japan. The authors would like to thank Mr. K. Inada and Mr. N. Yamaguchi (Center for Instrumental Analysis, Nagasaki University) for NMR and MS measurements.

\section{References}

1) Jiang Z., Zhou R., Masuda K., Ageta H., Phytochemistry, 40, 219224 (1995); Jiang Z., Tanaka T., Kouno I., ibid., 40, 1223-1226 (1995); Jiang Z., Inutsuka C., Tanaka T., Kouno I., Chem. Pharm. Bull., 46, 512-513 (1998).

2) Jiang Z., Tanaka T., Kouno I.,Tetrahedron Lett., 35, 2031-2034 (1994); Idem, Chem. Pharm. Bull., 44, 1669-1675 (1996).

3) Jiang Z., Tanaka T., Hirata H., Fukuoka R., Kouno I., Phytochemistry, 43, 1049-1054 (1996).

4) Jiang Z., Tanaka T., Kouno I., J. Chem. Soc., Chem. Commun., 1995, 
1467-1468; Tanaka T., Jiang Z., Kouno, I., Chem. Pharm. Bull., 45, 1915-1921 (1997); Jiang Z., Tanaka T., Kouno I., J. Nat. Prod., 62, 425-429 (1999).

5) Jiang Z., Tanaka T., Hirata H., Fukuoka R., Kouno I., Tetrahedron, 53, 16999-17008 (1997); Jiang Z., Tanaka T., Kouno I., Chem. Pharm. Bull., 47, 101-103 (1999).

6) Jiang Z., Fukuoka R., Aoki F., Tanaka T., Kouno I., Chem. Pharm. Bull., 47, 257-262 (1999).

7) Kawanishi K., Uhara Y., Hashimoto Y., J. Nat. Prod., 45, 637-639 (1982).

8) Tanaka T., Jiang Z., Kouno I., Phytochemistry, 47, 851-854 (1998).

9) Kusumi T., Ohtani I., Inouye Y., Kakisawa H., Tetrahedron Lett., 29,
4731 - 4734 (1988); Ohtani I., Kusumi T., Kashman Y., Kakisawa H., J. Am. Chem. Soc., 113, 4092- 4096 (1991).

10) Morihara M., Sakurai N., Inoue T., Kawai K., Nagai M., Chem. Pharm. Bull., 45, 820 - 823 (1997); Okuda T., Yoshida T., Hatano T., Koga T., Toh N., Kuriyama K., Tetrahedron Lett., 23, 3937-3940 (1982).

11) Kim S.-Y., Lee K.-S., Son J.-K., Je G.-H., Lee J.-S., Lee C.-H., Cheong C.-J., J. Nat. Prod., 61, 643-645 (1998).

12) Muller W.-U., Leistner E., Phytochemistry, 17, 1739-1742 (1978).

13) Takhtajan A., Systema Magnoliophytorum MCMLXXXVII, Leninopoli, 1987 (in Russian); Lu A., Zhang Z., Zhiwu Fenlei Xuebao, 28, 96-102 (1990) (in Chinese). 